\title{
Paying Back to Borrow More: Reputation and Bank Credit Access in Early America*
}

\author{
Ta-Chen Wang \\ Assistant Professor \\ Department of Economics \\ California State University, Sacramento \\ $6000 \mathrm{~J}$ Street \\ Sacramento, CA 95819-6082 \\ USA \\ tachen.wang@csus.edu
}

\begin{abstract}
The birth of commercial banking in New England after the American Revolution provides an important case to examine banking development under asymmetric information. Similar to credit markets in developing countries today, bank borrowers of early America usually had little or no collateral. This paper uses a unique data set based on loans between 1803 and 1833 for Plymouth Bank to examine bank lending policies in the absence of collateral. Empirical evidence suggests that borrowers with little collateral established their credit-worthiness through repeated interaction with banks.
\end{abstract}

\footnotetext{
* I would like to thank Gavin Wright for all his direction and endless patience. Ran Abramitzky, Farley Grubb, Stephen Haber, Michael Haupert, Jonathan Kaplan, Ron McKinnon, Benjamin Myers, Stephen Perez and Mark Siegler also provided helpful comments. This paper also benefited from comments from participants in the 2007 Social Science History Association Meeting and the 2008 Business History Conference. I would also like to thank the editor of this journal and two anonymous referees for their helpful comments. This research is supported by B.F. Haley and E.S. Shaw Fellowship and Stanford Graduate Research Opportunity Fund. All errors are mine.
} 


\section{Introduction}

Early bankers, like all other lenders, were faced with imperfect information in assessing loan risks. Lamoreaux (1994) argues that early banks in New England used kinship and personal ties to overcome this difficulty. Banks did not just lend to friends and family members because of their personal ties; they were willing to do so because they had more complete information on these individuals. A lender would not knowingly lend to a family whose members he knew to be untrustworthy. On the other hand, banks still lent to individuals outside of their personal networks. We know relatively little about how borrowers unrelated to bank officials were able to acquire and maintain access to credit.

The lack of collateral in modern small businesses echoes the situation in early American credit markets. Recent theoretical works, such as Diamond (1989), Boot and Thakor (1994), Petersen and Rajan (1995), and Martinelli (1997), evaluate the importance of relationships between banks and their borrowers. A particularly interesting question is how small businesses and startups acquire credit. Small businesses, with few assets as collateral, are particularly dependent on banking relationships. As specific banks and borrowers interact repeatedly, the borrowers gradually reveal valuable information to banks to build up a reputation, thereby securing future access to credit.

Specific conditions in early America further accentuated the role of reputation. First, no agency specialized in centralized credit history reporting; thus, banks had to collect information on borrowers themselves. Second, many banks remained local monopolies for extended periods. Therefore, from the banks' perspective, their monopoly status allowed them to internalize the benefit of collecting information. From the borrower's perspective, a good reputation with local banks secured funding for future 
opportunities. Once the reputation was built, it would be costly to switch to another bank without such private information.

This reputation mechanism is especially crucial in explaining a bank's loans to "outsiders." Although a large portion of lending was to bank directors, a fair share of loans went to individuals outside this inner circle. A bank's need for background information before extending loans to such individuals was particularly acute. ${ }^{1}$ After the first loan took effect, it was in the bank's interest to monitor borrowers' behavior and keep track of interest and principal payments. When the borrowers applied for subsequent loans, the information accumulated from the previous loans became crucial for the bank's lending decision.

This paper uses the records of the Plymouth Bank, in Plymouth, Massachusetts, between 1803 and 1833 to investigate the role of reputation in early bank lending. Specifically, I aim to answer the following questions. Did reputation matter in securing access to bank credit? If so, in what way did it affect borrowers? Was reputation crucial in the presence of collateral? Empirical evidence shows that, like today, borrowers first acquired small loans. They gradually built up their reputation by repaying the previous loans. Other things equal, each loan repaid would increase the amount of credit extended in the future. While borrowers' good reputation secured better credit access, reputation only mattered for loans without collateral. Therefore in the absence of collateral, reputation acted as a substitute. Over time, the gradual building of a cohort of reputable borrowers also changed the composition of the bank's clientele; the bank relied less on

\footnotetext{
${ }^{1}$ For example, Wright (2002b) explains how borrower's application letters were crucial in providing banks with detailed information on their property holdings. See Wright, (2002b), pp. 154-156.
} 
the existing network of insiders and more on the acquired information from repeated interaction with borrowers. This study not only helps us understand how the early American financial system functioned, but also to draw broader implications for the development of the early American economy. Indeed, access to bank credit enabled borrowers to invest in new ventures, thereby creating opportunities for growth and prosperity.

\section{Reputation in Credit Markets: Theory and Evidence}

The empirical question regarding the relationship between reputation, collateral, and loan terms corresponds to the general theory of reputation in market transactions. MacLeod (2007) discusses the role of reputation as a form of capital in a game-theoretical framework. Reputation is often used to enforce mutually beneficial contracts. Individuals build their reputation with others through repeated interactions. To prevent the breach of contract, denial of future trade opportunities is often imposed as a form of punishment. In other words, the breach of contract destroys the reputation capital previously accumulated. It is through this dynamic incentive that lenders deter borrowers from defaulting.

More specifically, the literature on credit markets focuses on the impact of information asymmetry on the interest rate, loan size, and collateral requirements. Stiglitz and Weiss (1981) demonstrate that because of adverse selection, credit rationing can exist even without a usury law. More recent literature, such as Diamond (1989), indicates that borrowers could start building their reputation by accepting less attractive loan contracts with higher interest rates. After individuals have established their reputations as good 
borrowers, they gain access to loans at better terms. Reputation in Diamond's model mitigates the incentive problem of moral hazard. Martinelli (1997) focuses on the role of limited loan size along with interest rate to mitigate such problems. On the other hand, Petersen and Rajan (1992) emphasize the rent-extraction aspect of monopolist banks. In their model, monopolist banks could offer relatively low interest rates for startups, only to charge higher interest when the borrower is locked in. In other words, the lender has the ability to allocate the rent across time. Boot and Thakor (1994) find that before borrowers can show success in their investment projects and pay off their bank loan, they have to borrow with collateral at higher interest rates. Once an investment succeeds, borrowers can receive loans at a lower rate and without collateral. It is the higher payoff of cheaper future loans that keeps the borrowers from moral hazard. In all of above analyses, variation in interest rate is a crucial element.

A similar focus also appears in literature on American banking history. Works by Adams (1972), Bodenhorn (1997), and Wright (1998) all collect data on individual banks and analyze their practices in the nineteenth century. More recent works, such as White (2001) and Bodenhorn (2003, 2007), use detailed loan records to study the effect of relationship and reputation on bank loans. White (2001) investigates the effect of reputation on loan rates using data from a private California bank in the late nineteenth century. He finds that the lending rate was affected by the previous credit history with the lender. As there was virtually no regulation on private banks in late nineteenth century California, the bank could charge interest as high as 40 percent. Thus, the bank was able to lend at high interest rates to high-risk or unknown borrowers. Bodenhorn (2003) uses data from a New York bank in the 1850s to analyze the effect of reputation on loan rates, 
collateral requirement and renegotiation of loans during the Crisis of 1857 . The empirical results confirm that borrowers with long relationships with the bank enjoyed lower interest rate and lower collateral requirements. Also, they were more likely to receive loan renewals during financial crises. In addition, Bodenhorn (2007) also finds that banks

would violate usury laws when the credit market tightened. However, borrowers would not jeopardize the valuable long-term relationships with the bank by filing usury suits.

Despite a growing literature on the relationship between lending rates, loan sizes and reputation, little empirical work examines the differential impact of repayment history for loans with and without collateral. To be sure, the use of reputation mechanism was not the only channel to provide a repayment incentive and thus credit access. Borrowers could also specify collateral with each loan. Literature on small business finance and economic development (Berger and Udell (1995), Fleisig (1996)) suggests that collateral is an important factor in credit availability. The extent to which reputation affects future credit access, a priori, is different for secured and unsecured loans. The following analysis specifically distinguishes the differential impact of repayment history on loan sizes for secured and unsecured loans.

\section{Data}

The analysis exploits a newly developed dataset from discount and stock records of the Plymouth Bank between November 1803 and September 1833 (Plymouth Bank Records, Volume 37-56, Notes for Discount and Volume 11, Journal, 1803-1845, Record of original shareholders in bank and transfer of shares). When Plymouth Bank began its operation in 1803, it was among one of the earliest banks in Massachusetts. It remained 
the sole bank in Plymouth County until 1828. However, it was not until 1832 that the Plymouth Bank faced direct competition within the town of Plymouth. ${ }^{2}$ This paper uses both discount records and stock records to investigate the role of reputation in bank lending.

The discount records contain every discount dating back to 1803, when the bank first started its operation. The data are especially valuable since they contain the names of every individual that had access to bank credit between 1803 and 1833. Each loan entry contains loan date, promissory, endorsers, and presenter of the loan, the amounts of loan, duration, and amounts discounted (as interest). ${ }^{3}$ All loans were called “discounts.” The records contain 1,689 new loans along with all subsequent renewals, all of which sum to 17,053 entries. The majority of early bank loans fell into two categories: accommodation paper and commercial paper. Each represented a different credit activity. The former was similar to a modern day bank loan, whereas the latter was the discount on a specific

\footnotetext{
${ }^{2}$ Ideally, the comparison of lending practices before and after the bank faced competition would be instructive in understanding the bank's behavior. However, the loan records are missing between 1833 and 1843 for unknown reasons. The discontinuity of the data prevents a comparative study on the effect of reputation on lending practices across time.

${ }^{3}$ Promisor refers to the original debtor of the debt, and presenter refers to the individual who brought the paper to the bank. In the case of an accommodation loan, the two names are the same. Endorsers were guarantors for the loan. This is because the borrowers presented the note to the bank and promised to pay back a certain amount in the future. For a commercial paper, these two names would differ. The promisor was the original drawer of the commercial paper and the presenter was the final holder of the paper, who brought the paper to the bank for discount. Endorsers in this case represents the recipient of the paper but sold the paper to a third party, potentially the presenter.
} 
commercial transaction. For the purpose of examining reputation effects, the distinction is crucial. Although the latter might originate from individuals in distant locations, they were also backed by the goods in the underlying transaction. The self-liquidating nature of commercial paper implies that these loans would not be renewed when due. ${ }^{4}$ Accommodation paper, on the other hand, was often renewed when due. A typical loan lasted for 60 days, but borrowers could renew their loans multiple times upon bank approval.

The original records only specify if a note was new or not. In order to determine the exact duration of each loan, including renewal, I trace every renewal for each loan to the very last entry. The process establishes the exact date of full repayment for each loan. Such information allows one to investigate the effect of repayment history on future loan sizes. In addition, it also provides valuable information regarding the nature of the loan because commercial paper would not be renewed.

Nineteenth century New England banks were known to practice "insider lending.” Banks usually lent extensively to their own directors. In addition, the directors were not a random group of individuals; they often maintained personal or business relationships with one another before establishing banks. This close-knit relationship between directors allowed an easy exchange of private financial information, and thus bank directors were more likely to extend loans to each other than to outsiders whose financial history was less certain. In this manner, bank directors came to possess easier access to bank credit.

\footnotetext{
${ }^{4}$ Technically, there was no distinction in the format of the entry for the two types of loans. However, one can usually identify a certain entry as commercial paper discount if the presenter of the note is different from the promisor of the note, and the amount ended in odd figures.
} 
In the presence of pre-existing relationships, reputation may not have been an important factor in credit access for bank directors. It is thus necessary to take into account the borrowers' relationship with the bank.

To identify the insiders of the bank, I used the charters of Plymouth Bank and local newspapers as primary sources. The president and the directors were often listed in the charter of the bank. However, since the bank acquired its first charter in 1803, with renewals in 1812 and 1832, the information is sporadic at best. Local newspapers often publish the election results of bank directors and presidents. ${ }^{5}$ However, this information for Plymouth Bank was limited. ${ }^{6}$ Nevertheless, this is the most precise measure of the individual who possess advantages in borrowing through direct control over bank lending practices.

In addition to bank directors, a borrower's stockholding status may also be informative of his relationship with the bank. In the period under analysis, only a small group of individuals owned shares in the bank. These shareholders were likely to already have good relationships with the bank's founders, and the bank was thus more willing to lend to them. Stockholders could also borrow from the bank using these shares as

\footnotetext{
${ }^{5}$ The newspapers used are: Columbian Courier, 19 August, 1803, Columbian Centinel, 12 January, 1805 and New Bedford Mercury, 15 October, 1830.

${ }^{6}$ Combining these two sources, I was able to identify the directors in the following years: 1803, 1805, 1812 1830 and 1832. The long gap of data between the years 1812 and 1830 poses a potential problem of missing information. However, if the changes in the composition of directors were gradual, which was the case between 1803 and 1812, such loss would not be severe.
} 
collateral. In this case the discount records would specify "transfer of shares."7 This practice was common among New England banks (see Lamoreaux 1994). Furthermore, transferring shares to loans also implied that stockholders with more shares would be able to borrow more. Even if a specific loan was not explicitly backed by shares, bank stocks could be easily liquidated in case of default. The liquidity and popularity of bank stocks made them a perfect instrument as collateral, explicitly or implicitly.

To identify stockholders I use the stock ledger to compile a list of stockholders. The stock records list the names of all stockholders and their number of shares in 1803, when the bank first acquired its charter, and in 1812, when the charter was renewed. All transactions of shares between 1803 and 1812 and after 1812 also appeared in the records. Transactions are defined as all transfers of shares, including sales, liquidation, gifts (usually to heirs) and shares used as loan collateral. Using the initial records and all subsequent transactions, a daily stockholder's list is constructed between 1803 and 1833 . Combined with discount records, one can determine the number of shares a certain borrower owned when each loan was made.

In addition to information from the loan records and stock records, I also use the Federal Census of 1820 and the Plymouth Court Records to identify the occupation and location of residence for each borrower. Early banks were often organized by merchants; the bank directors could possess better information on their peers, and therefore favored loans to that group. Given the local nature of the credit markets in early nineteenth century, it is also essential to control for the location of borrowers. Adding these

\footnotetext{
${ }^{7}$ To be exact, in the entry of the discount books, the word "transfer" would appear as endorser. At the same time, stock records also shows that these shares were transferred to the cashier until the loan was paid off.
} 
variables allows for a more precise characterization of the reputation-building process. On the other hand, the occupation of some borrowers could not be identified. I excluded such borrowers from subsequent analysis; as a result, the sample size declines from 1,689 to 1,148 .

Was the situation in Plymouth representative of that in other banks throughout early America? The lack of comparable records from other banks in the region prevents direct comparison of lending practices. However, basic balance sheet information provides at least some measure of whether the situation at Plymouth Bank was typical of this time and place. ${ }^{8}$ Judging from its size of capital, outstanding loans, and profitability, Plymouth Bank in this period was not an outlier. In the period under investigation, its capital size was $\$ 100,000$, which is the median among all Massachusetts banks outside of Boston and Salem. ${ }^{9}$ A similar comparison can be made on the total amount of loans outstanding and profitability rate. Between 1803 and 1833, the average amount of loans outstanding was $\$ 125,017$, compared to other banks of the same size at $\$ 146,858$. Thus the asset of the Plymouth Bank was just below the average of comparable banks. While the banks' balance sheets do not provide any information concerning loan policies, they do confirm that Plymouth Bank was not an outlier in its size.

\section{Analysis on Banking Practices}

\subsection{Effect of Usury Law}

\footnotetext{
${ }^{8}$ The source of the data is Weber (2005).

${ }^{9}$ Multiple banks existed in Boston and Salem, the commercial and industrial center of the region. These banks often possess greater amount of capital. Since in this period their ability to extend loans was limited to twice the capital stock, their total amount of loans outstanding also tended to be greater.
} 
One major difference in early nineteenth century banking from today was the prevalence of usury laws. Whether the law was binding has often been debated. Wright (2002a) argues that banks as institutional lenders would be less willing to violate usury laws. ${ }^{10}$ Both individual lenders and banks were subject to fines if found charging usury rates. Furthermore, early banks were also chartered by the state. This means that, in addition to punishment for violating usury laws, the state could refuse to renew bank charters when the original charters expired. Rockoff (2003) carefully documents the literature on usury laws as well as court cases and concludes that usury laws could have been effective. Davis (1960) also argues that Massachusetts usury laws were well-observed by institutional lenders until mid-nineteenth century. On the other hand, Bodenhorn (2003, 2007) demonstrates that in free-banking era New York, banks did violate usury law when necessary; borrowers, with the intent to secure future credit access, had little choice but to accept the loan terms. This is not inconsistent with Rockoff (2003) or Wright (2002a). With the introduction of free-banking, the threat of losing a bank charter became less severe. As a result, the usury law could be less effective.

In early nineteenth century Massachusetts, the usury ceiling was 6 percent per year. In the Plymouth Bank Records, the discounts show no signs of violating such laws. All discounts in the dataset were charged at a 6 percent interest rate. ${ }^{11}$ Higher interest would have been conspicuously illegal. When the market rate was low, the bank could

\footnotetext{
${ }^{10}$ Wright (2002a), p. 31.

${ }^{11}$ Interestingly, one can observe above-usury rates in the loan records of Plymouth bank between 1844 and 1849. This observation is consistent with Rockoff (2003) in that the enforcement of usury law began to loosen in mid-nineteenth century. It also echoes Bodenhorn (2003, 2007).
} 
have lowered its interest rate at least to reputable borrowers. However, such low interest rates were not observed during the period under study. Thus the market rate must have been at least as high for loans of risks comparable to those of Plymouth. Potentially the bank could have required a fraction of a loan to be deposited as a compensating balance. Since compensating balances were interest-free, this practice effectively raised the interest rate on loans. However, from the records of deposit books, there is no evidence such method was used. The observation is consistent with Rockoff (2003) and Davis (1960).

The subsequent analyses will focus on the other term of bank loans-loan sizes. Regardless of whether the bank evaded usury laws, loan size was and is a common instrument for adjusting loans to borrower attributes. Conceptually, under the restriction of usury law, the bank could not vary loan terms on both interest rate and loan sizes. In this case the reputation effect would be fully embodied in the latter. On the other hand, if the bank violated usury laws and was able to vary both interest rate and loan size, the effect of reputation on loan size could be weaker. In this case, evidence showing that loan sizes grew with each successful repayment only strengthens the argument. Thus the finding that loan sizes increased with borrower experience, if anything, understates the case for a learning effect.

\subsection{Insider Lending and Information}

New England banks often relied on kinship ties to overcome the problem of information. Kinship ties facilitated the collection of information on borrowers as well as monitoring. Nevertheless, in the case of Plymouth Bank, loans to outsiders constituted a fair share of the total discounts. Figure 1 shows the yearly shares of total volume of discounts in 
dollars to bank directors and stockholders. At any specific point in time, only seven individuals acted as bank directors. The group of insiders once borrowed up to 30 percent of the bank's resources. As much as their presence was over-represented, the majority of the loans were made to borrowers other than the bank directors. The share of total loans made to outsiders continued to increase, reaching more than 90 percent after 1830. Even if one looks at the share lent to those who once owned stocks of the bank, in any given year between 1803 and 1833, the bank still lent at least 40 percent of its total discounts to non-stockholders. In the years after 1820, this share grew rapidly, reaching 70 percent in 1833. By either measure, the bank lent more to borrowers outside of the circle of insiders.

The growing share of loans to outsiders indicates that they were able to gain access to bank credit over time. The bank was able to identify credit-worthy borrowers without personal connections to these individuals. Despite a growing presence of outsiders, the bank was still very selective in extending loans; only small group of individuals in the region received bank credit. From a security point of view, the bank was indeed successful in reducing default risks. The observation also is consistent with the general description of New England banks: conservative lending policy and low default rates.

As the theoretical literature suggests, the borrower's reputation was crucial in the approval of loans without collateral. Presumably a borrower could start out small, and build up his reputation over time. Other things equal, the individual should be able to borrow greater amounts after he paid off his first few loans and established himself as a good borrower. Collateralized loans were different as they were secured. When faced with default, the creditor could attempt to recover the loan through the liquidation of the 
collateral, although this is not to say that the loan could be recovered without cost. For example, before a mortgage could take effect, the two parties needed to register at the office of the deeds at the county level. After default, either foreclosure or sale of mortgaged land would also have to go through administrative procedures. Throughout the paper, mortgage, commercial paper and transfer of shares are considered collateralized loans. Figure 2 demonstrates the percentage of outstanding collateralized loans by year. The numbers are calculated by weighting the amount of each discount with its respective duration. In any given year, the percentage of secured loans out of all outstanding loans never exceeded 25 percent.

Table 1 presents the summary statistics of the amount of non-collateralized loans between 1803 and 1833. I group all loans by individual borrowers and order them chronologically from the first discount to the tenth. A few individuals borrowed more than ten times, but the sample size was too small to be meaningful. In order to control for the variation in price level, the discount amounts are deflated using David-Solar price index. The table also distinguishes insiders from outsiders. The bank possessed private information on insiders, while outsiders may need repeated repayments to demonstrate their credit-worthiness. Table 1 confirms this conjecture: the average and median loan sizes for outsiders demonstrate an upward trend as loan order increases, while those for insiders fluctuated with no obvious pattern. This suggests a reputation building process for the outsiders.

The increasing loan size of Table 1, although interesting, could have originated from economic expansion in early nineteenth century. Loan sizes might have grown larger over time simply because of the growing credit needs from a more vibrant 
economy. One method to check this hypothesis is to look at the amount of first loans over the sampling period. If economic conditions were the driving force, the amount of first loans should exhibit an upward trend over the years. Figure 3 documents the mean amount of first loans by year. The series shows no apparent upward trend. Therefore the increase in loan amount as an individual borrowed more times may not be the result of a general economic trend. To more closely examine the process of reputation building, one also needs to consider other factors. Some occupations might have relied on reputation more than others. Even among insiders, some might have owned more shares and thus had more collateral when borrowing from the bank. Commercial papers were selfliquidating, so it was relatively easy to recover the debt during default. Mortgages were also less costly for banks to recover in the case of default.

Another complementary mechanism to overcome asymmetric information was the threat of denial of future credit access after default. Plymouth Bank, like most contemporary New England banks, lent conservatively. As a result, defaults were rare throughout the period under examination. In this period, debtor's prison was still in place in Massachusetts, which may have further deterred borrowers from defaulting. In the few default cases, the bank stopped lending to these borrowers. ${ }^{12}$ This evidence is consistent with the use of reputation mechanism. The inability to repay loans would terminate the credit relationship, which imposed a substantial cost to borrowers a priori and acted as a potential deterrent to borrowers' opportunistic behavior.

\footnotetext{
${ }^{12}$ The two default cases are Jonathan Holmes and Paul Bailey Jr. in 1805. The Bank won the default cases in court and did not lend to these borrowers subsequently, despite that both appeared in the 1810 census.
} 


\section{Regression Analysis}

\subsection{Variables}

When reputation is crucial in securing credit access, one would expect an individual without a credit history to start by borrowing small amounts. The size of subsequent loans would increase as the borrower establishes credit. The process is similar to establishing one's credit history today. In addition, the usury laws in early nineteenth century could have precluded the possibility of raising interest rates to compensate for credit risks. Consequently, loan sizes captured the effect of reputation in this period more precisely than in modern days. As the source of the data spanned approximately 30 years, price fluctuations could taint the regression results. In order to control for changes in price level, I use David-Solar index to deflate the loan sizes. The real value of the loans is thus used as the dependent variable. The next section describes the explanatory variables in the regression models.

To examine the growth of loan sizes, one needs the information on the order of loans for each borrower. The variable history records the number of loans that has been paid off before the bank approved the current loan and takes on positive integers. It measures the borrower's track record not by the number of previous loans but by the number of loans that was paid off. This rules out the scenario in which multiple loans remained outstanding but none repaid. A priori, the coefficient on history should be positive, meaning that as the borrowers repaid more loans, they established their creditworthiness and the bank was more willing to increase the loan size. However, this interpretation can be dubious without other control variables. For a borrower with a long history with the bank, it was possible that the growing loan size simply reflected the 
rising demand for credit as the borrower became more successful over time. Because the number of repaid loans was correlated with the time elapsed since the first loan, a positive coefficient could simply be the result of business expansion. To isolate the effect of reputation on loan sizes from growth of credit demand, I incorporate in the regression models the number of days since the borrower took the first loan, which captures the growth of individual credit needs over time.

Other than past repayment history, the duration of previous loans may also provide important information on the credit-worthiness of the borrowers. When a borrower needed a long period of time to pay back the loan, the bank might infer that loans made to them would be riskier. As a result, the subsequent loan size may be smaller. A priori, the coefficient to this variable is expected to be negative.

The nature of collateralized loans may be another determinant in bank lending practice. As mentioned earlier, having pledged collateral greatly reduced the risk to the bank since it provided security in case of default. Consequently, the bank might not need to rely on reputation in the presence of collateral. They viewed collateral as a substitute for reputation. Empirically, this implies that the repayment history only matters for loans without collateral. To facilitate the direct comparison, the following analysis uses the negative dummy variable non-collateral to highlight such differences. ${ }^{13}$

The analysis incorporates different measures of the borrower's relationships with the bank, such as borrower's occupation and stockholding status. The most direct

\footnotetext{
${ }^{13}$ To be exact, collateralized loans includes mortgages, stock transfers and commercial papers. However, these characterizations are less important for the purpose of this study as all three kinds of loans were secured.
} 
measure among them is the distinction between insiders and outsiders. Insiders, following Lamoreaux (1994), are defined as bank directors. In addition to bank directors as controls, the regression model also specifies if a borrower had owned shares of the bank before each loan took effect. The shares of the Plymouth Bank in this period were held by a relatively small group of individuals. Therefore, the ability to purchase the stock may indicate that the individual had personal connections with the bank.

Other than the control of stockholders, I also include the number of shares a borrower owned at the time of loan. The number of shares measures the possible collateral by stock on each loan, either explicitly or implicitly. In some cases, a stockholder simply transferred his shares to receive a loan. Therefore, the more shares one owned, the greater the loan size could be. Even if the loan was not the hypothecation of stock shares, the high liquidity of bank stocks still provided a popular means of implicit collateral when the borrower defaulted.

Occupation is another important borrower characteristic. Among all occupation groups, it is particularly important to identify merchant borrowers. In the context of early nineteenth century Massachusetts, the relative importance of trade and commerce translated to strong demands for credit from merchants. Most early New England banks were formed by merchants to provide convenient access to credit. Large and successful merchants were also more likely to be known for their credit-worthiness. Thus, it is natural to presume that merchants were favored when the bank extended credit. Consequently, the following analysis specifically distinguishes merchant borrowers from other groups. 
The local nature of early credit markets implies that distance of borrowers' residence from the bank could be an important factor in the bank's loan decision. In addition to occupation, census and court records also provide the information about the township in which borrowers resided. ${ }^{14}$ Interestingly when analyzing the effect of borrowers’ proximity on loan sizes, two different and opposing effects emerge. First, for distant borrowers, information collection ex ante and debt collection ex post may have been more difficult. Accordingly, other things equal, the bank might have been less willing to lend great amounts. The second effect relates to borrower self-selection in the loan application process. Those distant borrowers who successfully acquired bank loans were likely to be well-known to the bank. This potential selection bias may have resulted in larger amounts lent to distant borrowers. Because borrower proximity may have these two opposing effects, it is difficult to ascertain the net effect of distance on loan sizes.

To control for the effect of economic fluctuations on loan sizes, the model also includes year and month dummies to control for the timing of the loan. The yearly controls reflect the general conditions in the credit market and local economy. Presumably, in times of economic downturn, such as the embargo of 1807 to 1809, and the financial crisis of 1819, banks were less willing to lend large amounts. On the other hand, the long-term trend toward economic growth from 1803 to 1833 might have resulted in growing loan sizes. Because loan sizes may also vary by month, the models

\footnotetext{
${ }^{14}$ The variable distance takes the dummy form. Individuals living in the town of Plymouth and contiguous towns serve as the benchmark for the distance dummy. For borrowers residing outside of this region, the value of the distance variable is set to 1 . More elaborate construction of the distance variable does not change the result of the analysis.
} 
also incorporate monthly dummies. For example, loans to farmers tended to be smaller and occurred more often at the beginning of the growing season. Ideally, one would like to capture the effect of business cycles and seasonal effects with time-series techniques. However, the structure of the data does not allow for easy application of traditional timeseries methods.

\subsection{Summary of Data}

The regression analysis uses the 1,148 new loans from the discount records. A total of 222 borrowers generated these loans. Large variation existed in the number of new loans each borrower received. 70 individuals only appeared once in the loan records, while 11 borrowers received more than 20 new loans. Table 2 summarizes the frequency of borrower characteristics and loan types, along with the amount and duration of loans associated with these qualitative variables. The first two columns tabulate the frequency of each category and sub-category. The third and fourth columns present the average loan size and duration extended to each group of borrowers. The last column is the percentage of loans by each group, weighted by duration and size, which serves as a measure of the total bank resources occupied by each group. Not surprisingly, merchants received a majority of loans, both in terms of number of loans and the shares of financial resources. ${ }^{15}$

In addition to merchants, bank directors and stockholders also deserve special attention. Table 2 illustrates that although bank directors only made up 179 loans, their average loan size was the greatest among any groups under different categorizations.

\footnotetext{
${ }^{15}$ Although the average duration of loans to merchants was shorter than non-merchants because of the use of commercial paper, the greater loans sizes more than compensate for it.
} 
These 14 individuals enjoyed almost 27 percent of the total loans, weighted by loan sizes and duration. Loans to stockholders made up more than half of the bank's resources in the sample; this is especially prominent considering only a total of 39 stockholders borrowed from the bank. Like loans to bank directors, the loan sizes to stockholders also tended to be greater. The over-representation of bank directors and stockholders in the loan records is consistent with Lamoreaux (1994). Among different loan types, collateralized loans constituted only 17 percent of the bank's total lending. Most of these took the form of commercial paper, which could not be renewed and thus had the average duration of just more than 49 days. While the bank did not lend extensively in the form of mortgages, such loans were often long-term and each renewal could last for a full year. Geographically, the bank lent more to people within the town of Plymouth and adjacent towns, although it also lent to distant borrowers.

The summary statistics demonstrate that bank insiders and stockholders had better access to bank credit. However, non-stockholders still were able to secure the remainder of bank credit. In addition, the majority of the bank's lending was committed to accommodation papers. The following section uses regression analysis to investigate how reputation and credit history affect loan sizes, especially for unsecured loans.

\subsection{Regression Results: Reputation and Loan Size}

Table 3 presents the regression results. In Model 1, I use the variable history to measure the increment of loan size after each previous loan was paid off. The coefficient is significant at the 1 percent level. Borrowers with longer repayment history received larger loans. The benchmark for the basis of comparison is a bank director who held the bank shares and was also a local merchant. Bank directors, stockholders, and merchants 
were able to receive larger loans. This is in accordance with the theoretical predictionsall of these dummy variables capture the potential information advantages of familiar borrowers. Model 2 adds an interaction term between history and unsecured loans. The coefficient was positive and significant, suggesting that personal repayment history was particularly important for individuals who did not use collateral when applying for a loan. From another angle, collateral could be used as a substitute for reputation if the borrower had not already accumulated a credit history with the bank.

To formally test the difference in lending practices between secured and unsecured loans, we need an equation that includes both collateralized and noncollateralized loans and controls for both set of observations. Model 3 is estimated using all controls in model 1 , along with their interaction terms with the dummy for noncollateral loans. The first column under model 3 reports the coefficients without incorporating the interaction terms; hence the coefficients capture the effect of explanatory variables on loan sizes for collateralized loans. The second column reports the same coefficients for loans without collateral, which is calculated by adding coefficients of the interaction terms to those in the first column. The last column reports the coefficients to the interaction term, thereby capturing the differential impact of the explanatory variables on loan sizes between loans with and without collateral. All year and month controls and their interactions with non-collateralized loans are also included. The regression output shows that the coefficient on past repayment history is significant for unsecured loans, but insignificant for secured loans. Moreover, the difference between these effects is statistically significant. The implication is that reputation, embodied by 
past repayment history, played a crucial role in determining the sizes for accommodation loans but had virtually no effect on secured loans.

Other than the effect of past credit history, the regression also shows that borrower characteristics had much stronger impacts on loan sizes for unsecured loans. Secured loans made to bank directors and stockholders were not significantly larger than those made to outsiders. However, the effects of being a non-stockholder and outsider are negative and significant for unsecured loans. These regression results imply that the bank treated collateralized and non-collateralized loans differently. Moreover, the comparison between different models also shows that the significant coefficients on borrower characteristics in model 1 were driven by unsecured loans rather than all loans in the sample.

A priori, the average duration of previous loans provided information on the borrower's ability to pay back his debt in time. However, the effect of previous loan duration on present loan size is insignificant in the regression outcome. The explanation lies in the endogeneity of loan renewals; banks were more likely to renew loans for reputable borrowers. Hence the long duration could be a reflection of the borrower's credit-worthiness. This is consistent with Bodenhorn (2003), who shows that established borrowers were more likely to receive loan renewals during economic crises.

Another coefficient worth noting is that of borrowers' distance from the bank. In a local economy, distant borrowers tended to suffer more from imperfect information and thus were lent smaller amounts, although some significant long-distance credit relationships were observed. In this regard, the regression output suggests that, other things equal, the size of loans to distant borrowers was greater. In other words, despite 
the geographical distance, these borrowers were able to maintain favorable credit relationships with the bank.

Several Boston merchants, who received large loans from the very beginning of the bank, account for the observed effect of borrowers' distance on loan sizes. Among long distance borrowers, three stand out: Cornelius Coolidge, Jonathan Hastings and Samuel Spear. Cornelius Coolidge was born to one of the most prestigious families in Boston and graduated from Harvard College in 1798. He later became a successful merchant and architect in Boston. The discount records show that before 1807, 83 out of the 87 discounts made to Cornelius Coolidge were short-term commercial papers. It was not until after 1807 that he began to receive large accommodation loans in longer terms. In addition, he engaged in land purchases with Barnabas Hedge, a director of the Plymouth Bank in 1819. ${ }^{16}$ This further suggests that, at the time of his first loan, Coolidge was not only already successful, but also might have maintained business relationships with the directors of the Plymouth Bank.

Samuel Spear appeared in Plymouth Court Records five times before 1803, all as plaintiff in debt litigation against residents in Plymouth County. It is reasonable to believe that these cases represent but a small fraction of his commercial dealings with people in Plymouth County. Therefore, Spear was likely to have already established longstanding business relationships in the region before the bank was founded. The information on Jonathan Hastings is limited. However, the Tax List of 1798 indicated that he owned a dwelling house worth $\$ 4,950$ in Boston. His direct connection to

\footnotetext{
${ }^{16}$.New England Historical and Genealogical Register, Vol. 46. pp.79-80.
} 
Plymouth County is less clear. Nevertheless, the sheer value of his property indicates that at the founding of the Plymouth Bank, he was already very wealthy.

After leaving out these three observations from the sample, the significance of the coefficient vanishes. Most importantly, the main results remain robust; coefficient to past repayment history remains positive and significant only for non-collateralized loans regardless of the changes in the sample. ${ }^{17}$

\section{Conclusion}

One major distinction of early banks from other credit sources was their ability to pool financial resources, thereby extending larger loans. For many small borrowers, bank loans were the only possible source for credit beyond the value of their properties. Like lenders in the developing economies today, early American banks were faced with asymmetric information. This paper investigates how banks collect information in a local setting. Specifically, it focuses on the information flow after the first loans. Empirical results show that in the early stage, the bank tended to lend smaller amounts to new

\footnotetext{
${ }^{17}$ I have also tried other specifications to check robustness of the results. One potential problem was the price index. Instead of deflating with David-Solar index, I also used Massachusetts farm price index by Rothenberg (1979). From the standpoint of asset allocation, one can also argue that the loan sizes should not be deflated at all. The main results are robust against these variations. In addition to the issue of price level measurement, I also attempted alternative setups for the regression analysis, such as including quadratic terms of repayment history, and interactions between non-stockholder, non -collateral and repayment history. Another concern is the attrition of sample size from 1,689 to 1,148 when including the information of borrower occupation and location. Therefore alternative models using all 1,689 loans without variables controlling occupation and location are also estimated. In all of these models the results remain robust.
} 
borrowers. In this process, borrowers earned access to larger loans after paying off their earlier debts. Therefore the accumulation of personal reputation played a vital role in securing future credit access. The results echo those in Bodenhorn (2003), who demonstrates that firms having long-term relationships with banks enjoyed more favorable loan terms.

In addition, the role of reputation was particularly prominent when loans were not backed by collateral. In other words, the bank used borrowers' reputation as a substitute for collateral. Literature in economic development, such as Fleisig (1996), Besley (1995), Morduch (1999), and Armendáriz de Aghion and Morduch (2000) all suggests that when collateral is insufficient or simply non-existent, lenders seek alternative mechanisms to secure loans and avoid moral hazard. In the case of the Plymouth Bank, the directors resorted to reputation and the threat of denial of future credit to achieve these goals. The process implies that in the context of a local economy, the notion of "insiders" might not have been static. New borrowers could demonstrate their ability to pay back loans over time, thereby establish their credit-worthiness. The reputation building process enabled more individuals to access bank credit. They have become, in a sense, insiders. 


\section{References}

Adams, D. R., 1972. The Bank of Stephen Girard, 1812-1831. Journal of Economic History 22, pp. 841-868.

Armendáriz de Aghion, B., Morduch, J, 2000. Microfinance Beyond Group Lending. The Economics of Transition 8, pp. 401-420.

Berger, A.N., Udell G.F., 1995. Relationship Lending and Lines of Credit in Small Firm Finance. Journal of Business 68, pp. 351-381.

Besley, T., 1995. Savings, Credit, and Insurance. In: Behrman, J, Srinivasan, T.N. (Eds.), Handbook of Development Economics. Vol. 3A. Elsevier, Amsterdam, pp. 21232207.

Bodenhorn, H., 1997. Private Banking in Antebellum Virginia: Thomas Branch \& Sons of Petersburg. Business History Review 71, pp. 513-542.

Bodenhorn, H., 2003. Short-Term Loans and Long-Term Relationships: Relationship Lending in Early America. Journal of Money, Credit, and Banking 35, pp. 485505.

Bodenhorn, H., 2007. Usury Ceilings and Bank Lending Behavior: Evidence from Nineteenth-Century New York. Explorations in Economic History 44, pp. 179202.

Boot, A.W.A., Thakor, A.V., 1994. Moral Hazard and Secured Lending in an Infinitely Repeated Credit Market Game. International Economic Review 35, pp. 899-920.

Columbian Centinel, 12 January, 1805.

Columbian Courier, 19 August, 1803. 
Davis, L.E., 1960. The New England Textile Mills and the Capital Markets: A Study of Industrial Borrowing, 1840-1860. Journal of Economic History 20, pp. 1-30.

Diamond, D., 1989. Reputation Acquisition in Debt Markets. Journal of Political Economy 97, pp. 828-862.

Fleisig, H., 1996. Secured Transactions: The Power of Collateral. Finance and Development 33, pp. 44-46.

Lamoreaux, N., 1994. Insider Lending: Banks, Personal Connections, and Economic Development in Industrial New England. Cambridge University Press, Cambridge.

MacLeod, W.B., 2007. Reputations, Relationships, and Contract Enforcement. Journal of Economic Literature 45, pp. 595-628.

Martinelli, C., 1997. Small Firms, Borrowing Constraints, and Reputation. Journal of Economic Behavior and Organization 33, pp. 91-105.

Morduch, J., 1999. The Microfinance Promise. Journal of Economic Literature 37, pp. 1569-1614.

New Bedford Mercury, 15 October, 1830.

New England Historic Genealogical Society. 1892. New England Historical and Genealogical Register. Vol. 37-52. Boston, MA.

Petersen, M.A., Rajan, R.G., 1995. The Effect of Credit Market Competition on Lending Relationships. Quarterly Journal of Economics 110. pp. 407-443.

Plymouth Bank, 1803-1875. Vol. 11, Journal, 1803-1845, Vol. 37-55, Notes for Discount, 1803-1833. Historical Collections, Baker Library. Harvard Business School. Boston, MA. 
Quinquaennial Catalogue of the Officers and Graduates of Harvard University, 1636 1915. 1915. Harvard University Press, Cambridge, MA.

Rockoff, H.T., 2003. Prodigals and Projectors: An Economic History of Usury Laws in the United States from Colonial Times to 1900. NBER Working Paper No. W9742.

Rothenberg, W.B., 1979. A Price Index for Rural Massachusetts, 1750-1855. Journal of Economic History 39, pp. 975-1001.

Stiglitz, J.E., Weiss A., 1981. Credit Rationing in Markets with Imperfect Information. American Economic Review 71, pp. 393-410.

Weber, W. E., 2005. Balance Sheets for U.S. Antebellum State Banks. Research Department, Federal Reserve Bank of Minneapolis. http://research.mpls.frb.fed.us/research/economists/wewproj.html.

White, E.N., 2001. California Banking in the Nineteenth Century: The Art and Method of the Bank of A. Levy. Business History Review 75, pp. 297-324.

Wright, R.E., 1998. Artisans, Banks, Credit, and the Election of 1800. Pennsylvania Magazine of History and Biography 122, pp. 211-239.

Wright, R.E., 2002a. The Wealth of Nations Rediscovered. Cambridge University Press, New York.

Wright, R.E., 2002b. Hamilton Unbound-Finance and the Creation of the American Republic. Greenwood Press, Westport, Connecticut. 
Table 1. Amount of Non-Collateral Loans by Order (in 1859 dollars)

\begin{tabular}{|c|c|c|c|c|c|c|}
\hline $\begin{array}{l}\text { Loan } \\
\text { Order }\end{array}$ & \multicolumn{3}{|c|}{ Outsider } & \multicolumn{3}{|c|}{ Insider } \\
\hline & $\begin{array}{r}\text { Number of } \\
\text { observations }\end{array}$ & $\begin{array}{r}\text { Mean } \\
\text { loan } \\
\text { size }\end{array}$ & $\begin{array}{r}\text { Median } \\
\text { loan } \\
\text { size }\end{array}$ & $\begin{array}{c}\text { Number of } \\
\text { observations }\end{array}$ & $\begin{array}{r}\text { Mean } \\
\text { loan } \\
\text { size }\end{array}$ & $\begin{array}{r}\text { Median } \\
\text { loan } \\
\text { size }\end{array}$ \\
\hline 1 & 180 & 403.9 & 260.3 & 5 & 721.6 & 441.2 \\
\hline 2 & 123 & 370.7 & 281.7 & 7 & 1017.0 & 992.9 \\
\hline 3 & 93 & 373.2 & 252.1 & 6 & 428.4 & 388.6 \\
\hline 4 & 63 & 439.0 & 283.7 & 8 & 590.1 & 529.9 \\
\hline 5 & 41 & 423.7 & 331.1 & 8 & 1265.6 & 706.7 \\
\hline 6 & 37 & 485.1 & 270.3 & 5 & 682.7 & 385.1 \\
\hline 7 & 24 & 444.1 & 329.0 & 5 & 849.5 & 390.1 \\
\hline 8 & 22 & 586.8 & 433.4 & 6 & 514.4 & 316.9 \\
\hline 9 & 16 & 301.8 & 283.7 & 6 & 466.5 & 387.4 \\
\hline 10 & 15 & 508.6 & 521.3 & 4 & 1018.5 & 1123.7 \\
\hline
\end{tabular}

Note: the numbers of observations on the insiders are not monotonically decreasing. This is because for some insiders, collateralized loans appeared first. 
Table 2. Summary of Qualitative Variables

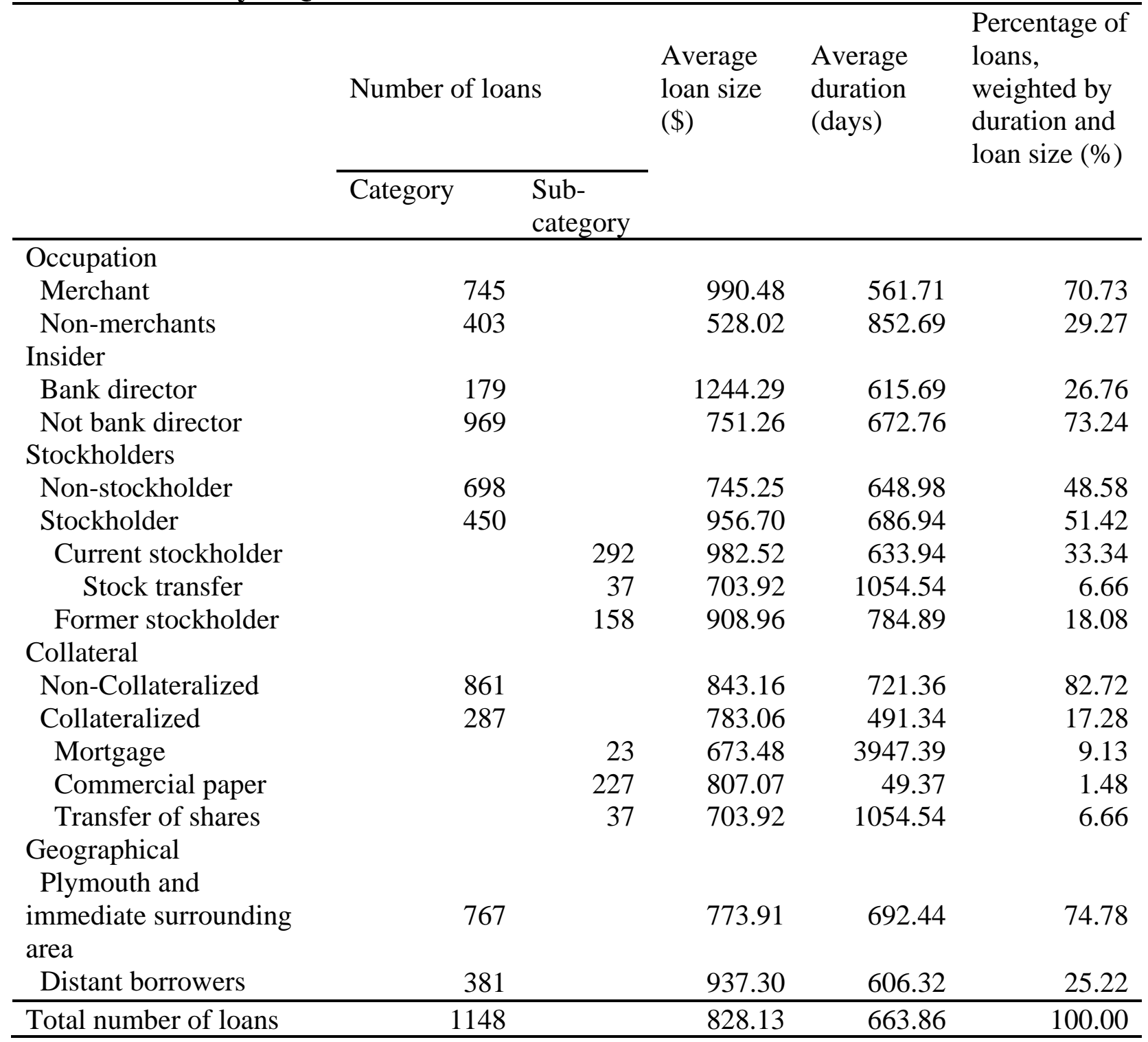

Note: To be consistent with the regression sample, the numbers are calculated based on the 1,148 loans after the borrowers' occupations and town of residence are identified. In categories other than occupation and geographical distance, it is possible to use the full sample of 1,689 loans. The main conclusion that stockholders and bank directors are over-represented remains unchanged. 
Table 3. Regression Output: Loan Sizes

\begin{tabular}{|c|c|c|c|c|c|}
\hline \multirow[t]{2}{*}{ Variable } & \multirow[t]{2}{*}{ Model 1} & \multirow[t]{2}{*}{ Model 2} & \multicolumn{3}{|l|}{ Model 3} \\
\hline & & & With collateral & $\begin{array}{l}\text { Without } \\
\text { collateral }\end{array}$ & $\begin{array}{l}\text { Coefficient of } \\
\text { interaction } \\
\text { term (loans } \\
\text { without } \\
\text { collateral) }\end{array}$ \\
\hline History & $\begin{array}{l}17.96^{* * *} \\
(2.10)\end{array}$ & $\begin{array}{l}1.26 \\
(2.24)\end{array}$ & $\begin{array}{l}-0.55 \\
(2.58)\end{array}$ & $\begin{array}{l}27.85^{* * *} \\
(2.08)\end{array}$ & $\begin{array}{l}28.40 * * * \\
(3.32)\end{array}$ \\
\hline $\begin{array}{l}\text { History*non- } \\
\text { collateral }\end{array}$ & & $\begin{array}{l}26.52^{* * *} \\
(3.00)\end{array}$ & & & \\
\hline $\begin{array}{l}\text { Number of days } \\
\text { since first loan }\end{array}$ & $\begin{array}{l}-0.01 \\
(0.01)\end{array}$ & $\begin{array}{l}-0.02^{*} \\
(0.01)\end{array}$ & $\begin{array}{l}0.03 \\
(0.04)\end{array}$ & $\begin{array}{l}-0.02 * \\
(0.01)\end{array}$ & $\begin{array}{l}-0.06 \\
(0.04)\end{array}$ \\
\hline $\begin{array}{l}\text { Mean duration of } \\
\text { previous loans }\end{array}$ & $\begin{array}{l}-0.06 \\
(0.07)\end{array}$ & $\begin{array}{l}-0.03 \\
(0.07)\end{array}$ & $\begin{array}{l}-0.22 \\
(0.24)\end{array}$ & $\begin{array}{l}-0.04 \\
(0 / 07)\end{array}$ & $\begin{array}{l}0.17 \\
(0.25)\end{array}$ \\
\hline Non-stockholder & $\begin{array}{l}-155.66^{* * * *} \\
(43.83)\end{array}$ & $\begin{array}{l}-115.04 * * * \\
(43.24)\end{array}$ & $\begin{array}{l}62.31 \\
(96.43)\end{array}$ & $\begin{array}{l}-125.17^{* *} \\
(48.60)\end{array}$ & $\begin{array}{l}-187.48 \\
(107.99)\end{array}$ \\
\hline Outsider & $\begin{array}{l}-184.10^{* *} \\
(72.64)\end{array}$ & $\begin{array}{l}-172.22 * * \\
(72.04)\end{array}$ & $\begin{array}{l}-154.29 \\
(116.05)\end{array}$ & $\begin{array}{l}-216.55^{* * *} \\
(95.03)\end{array}$ & $\begin{array}{l}-62.26 \\
(150.00)\end{array}$ \\
\hline Non-merchant & $\begin{array}{l}-142.75^{* * *} \\
(33.21)\end{array}$ & $\begin{array}{l}-163.10^{* * *} \\
(32.32)\end{array}$ & $\begin{array}{l}-233.73^{* *} \\
(95.67)\end{array}$ & $\begin{array}{l}-167.73^{* * *} \\
(35.64)\end{array}$ & $\begin{array}{l}65.99 \\
(102.09)\end{array}$ \\
\hline Distant borrower & $\begin{array}{l}89.51^{* *} \\
(39.04)\end{array}$ & $\begin{array}{l}124.52 * * * \\
(38.93)\end{array}$ & $\begin{array}{l}56.70 \\
(101.96)\end{array}$ & $\begin{array}{l}165.09 * * * \\
(42.14)\end{array}$ & $\begin{array}{l}108.39 \\
(110.33)\end{array}$ \\
\hline $\begin{array}{l}\text { Number of shares at } \\
\text { the time of loan }\end{array}$ & $\begin{array}{l}-0.75 \\
(1.07)\end{array}$ & $\begin{array}{l}-1.61 \\
(1.03)\end{array}$ & $\begin{array}{l}-1.06 \\
(1.98)\end{array}$ & $\begin{array}{l}-1.57 \\
(1.54)\end{array}$ & $\begin{array}{l}-0.51 \\
(2.51)\end{array}$ \\
\hline $\begin{array}{l}\text { Non-collateralized } \\
\text { loans }\end{array}$ & $\begin{array}{l}262.24 * * * \\
(51.38)\end{array}$ & $\begin{array}{l}-55.04 \\
(48.02)\end{array}$ & & & \\
\hline Constant & $\begin{array}{l}729.69 * * * \\
(188.03)\end{array}$ & $\begin{array}{l}972.24 * * * \\
(183.09)\end{array}$ & $\begin{array}{l}817.95 * * * \\
(306.17)\end{array}$ & $\begin{array}{l}1028.18^{* * *} \\
(217.14)\end{array}$ & $\begin{array}{l}210.23 \\
(375.35)\end{array}$ \\
\hline $\begin{array}{l}\text { Year and Month } \\
\text { Control }\end{array}$ & yes & yes & yes & & \\
\hline $\begin{array}{l}\text { Number of } \\
\text { observations }\end{array}$ & 1148 & 1148 & 1148 & & \\
\hline R-squared & 0.27 & 0.36 & 0.41 & & \\
\hline
\end{tabular}

Standard errors in parentheses

* significant at $10 \%$; ** significant at $5 \%$; *** significant at $1 \%$

Note: the following dummy variables are defined negatively: non-collateral, nonstockholder, outsider, non-merchant. For example, the value of the variable non-collateral for equals 1 for loans with collateral and 0 for loans without collateral. Similar setup also applies to non-stockholder and non-merchant. The Outsider variable equals 1 of the borrower was not a bank director and 0 otherwise. All standard errors are adjusted for heteroskedasticity. 
Figure 1. Percentage of Discounts to Stockholders and Insiders, 1803-1833

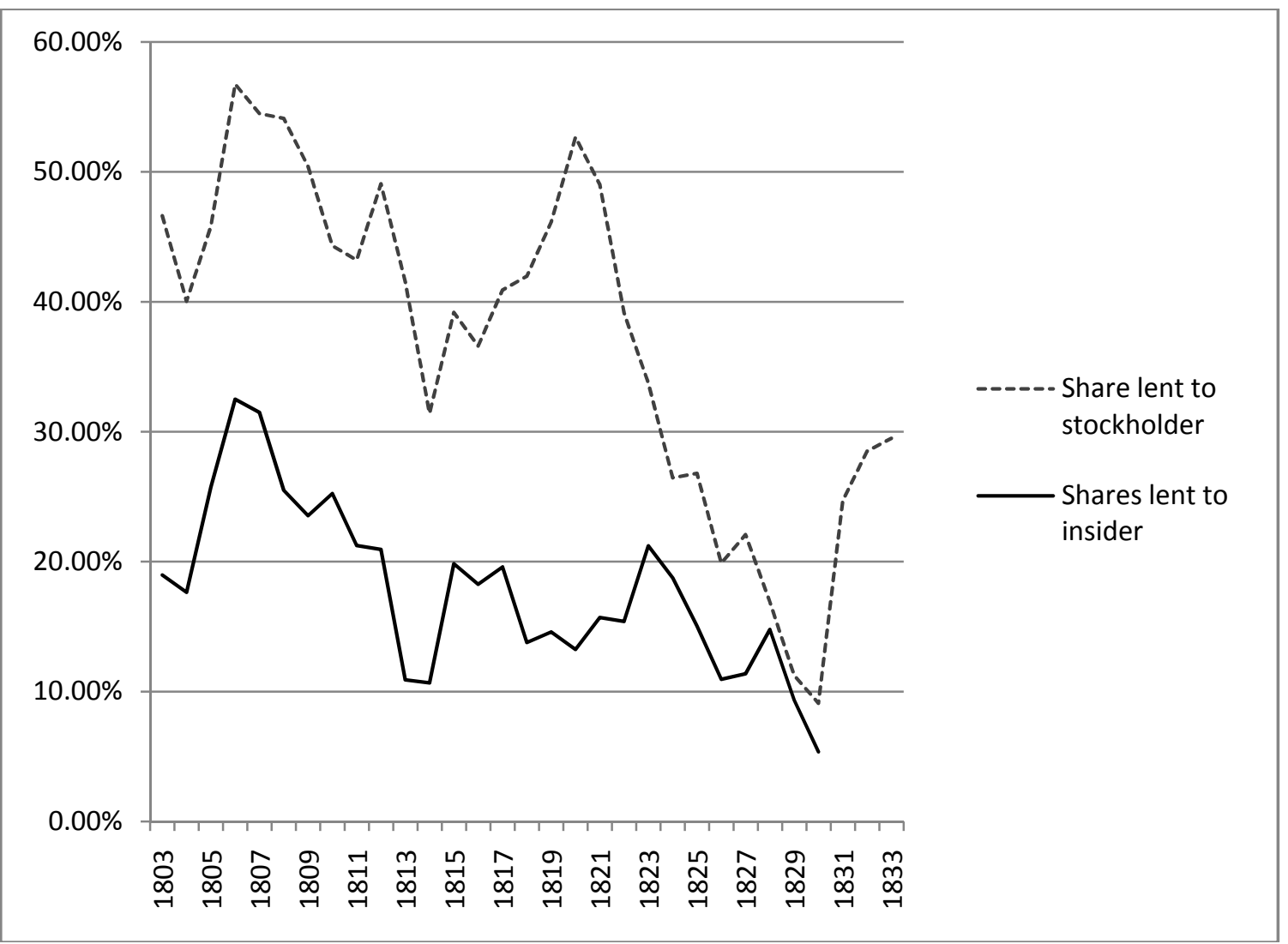

Note: The shares are calculated using all loan records by year, weighted by duration 
Figure 2. Percentage of Collateralized Loans by Year, Weighted by Duration

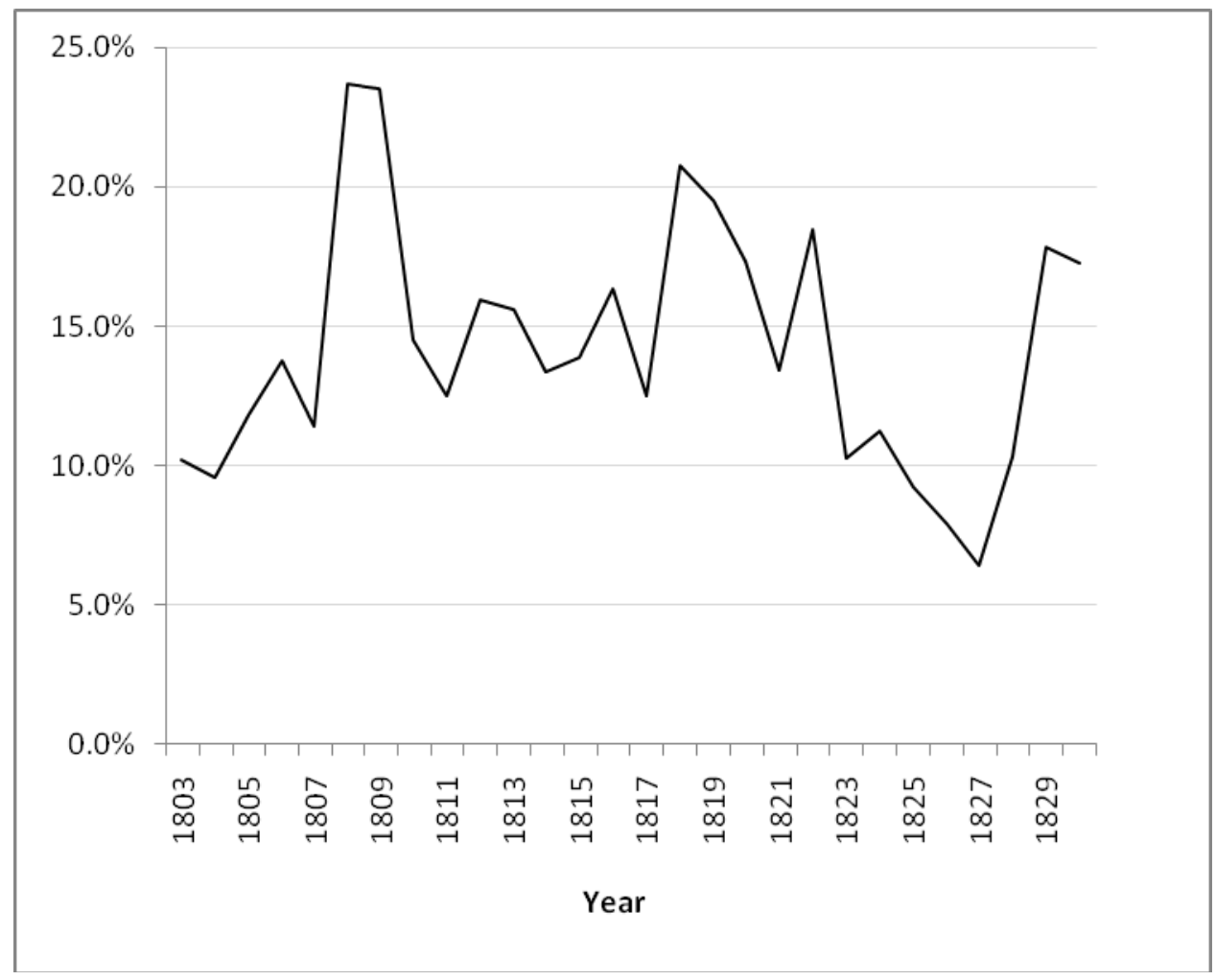


Figure 3. Average Amounts of First Loans by Year, 1803-1830

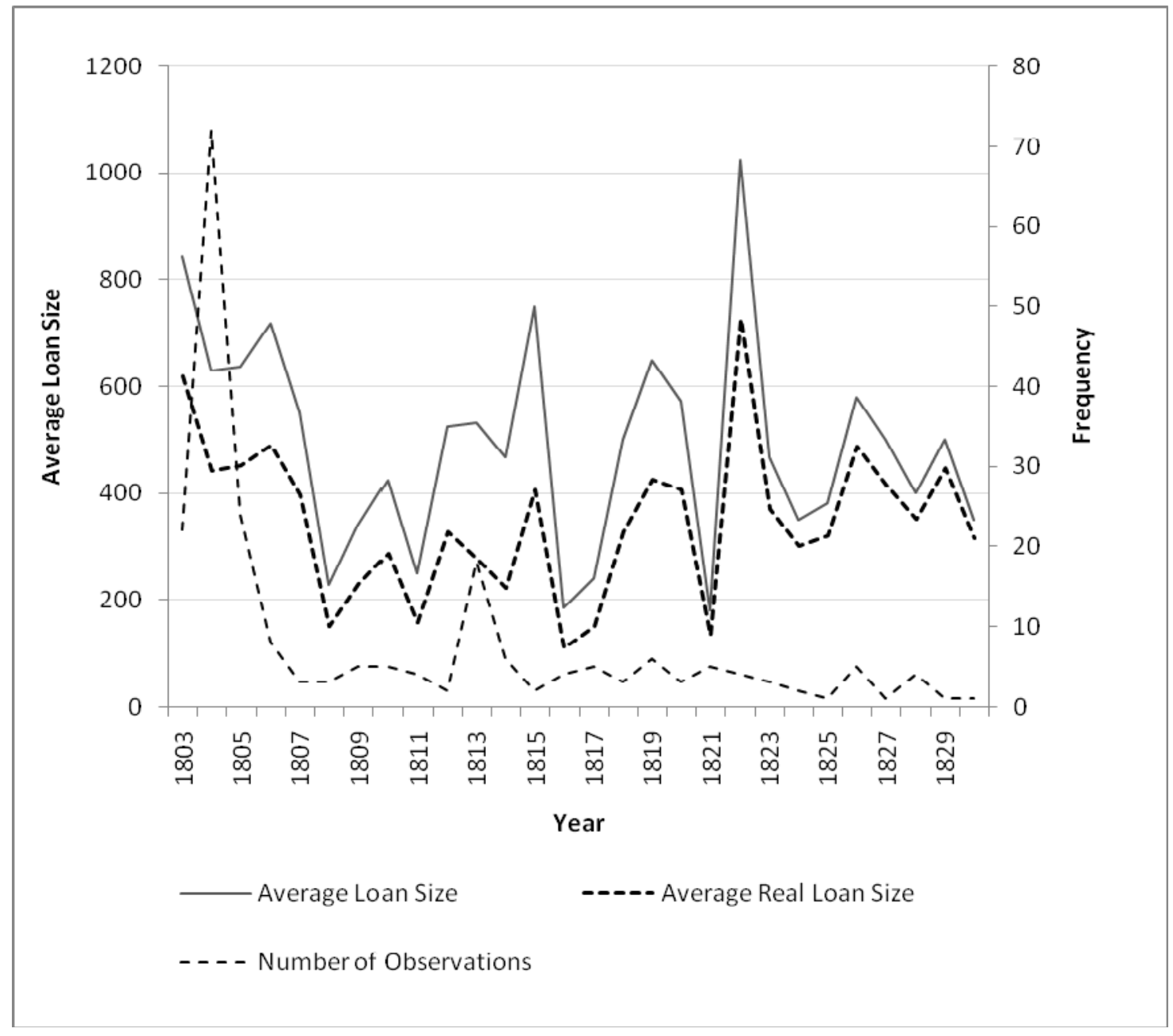

